\title{
FIRST OCCURRENCE OF A LINGULIDE (BRACHIOPODA: LINGULIDAE) AT PIAUÍ FORMATION (UPPER CARBONIFEROUS), PARNAÍBA BASIN, BRAZIL
}

\author{
CAROLINA ZABINI \\ Departamento de Geologia e Recursos Naturais, Instituto de Geociências, UNICAMP. Rua João Pandiá Calógeras, 51, Cd. \\ Universitária, Barão Geraldo, 13083-870, Campinas, SP, Brazil. Tel. +55 19 35214576. carolinaz@ige.unicamp.br

\section{LUIZ EDUARDO ANELLI \& JULIANA DE MORAES LEME} \\ Departamento de Geologia Sedimentar e Ambiental, Instituto de Geociências, USP. Rua do Lago, 562, Cd. Universitária, \\ 05508-080, São Paulo, SP, Brazil.anelli@usp.br,leme@usp.br
}

ABSTRACT - This paper presents the first possible occurrence of Lingularia in the Carboniferous of the Parnaíba Basin, Brazil. In addition, an attempt to clarify the classification of lingulids of Brazil and to demonstrate that the diversity of the group can still be better known and explored in the Brazilian basins is made.

Key words: Lingularia?, Esperança Member, taxonomy, Lingulida.

\section{INTRODUCTION}

Lingulids (Brachiopoda: Lingulida) have been recorded in Brazil from Ordovician to Devonian and through the Carboniferous of the Parnaíba and Paraná Basins (Rathbun, 1878; Clarke, 1913; Mendes, 1961; Bigarella et al., 1965; Gray, et al., 1985; Melo \& Boucot, 1990; Grahn \& Caputo, 1992; Zabini et al., 2007, 2010; Ponciano et al., 2012; Zabini et al., 2012, 2013; Queiroz et al., 2013). The Mesozoic has only one lingulid known from the Sergipe-Alagoas Basin: Lingularia? notialis (Holmer \& Bengtson, 2009). With the exception of the Discinoidea from the Devonian of the Paraná Basin, which have been recently redescribed (Comniskey, 2011; Zabini et al., 2013), lingulids from other periods remain to be correctly diagnosed; some of these fossils are referred as "Lingula" or "Orbiculoidea" when found in Brazilian Paleozoic strata and worldwide (Holmer \& Bengtson, 2009).

Fossils from Piauí Formation, Parnaíba Basin, are known since the early 1940's and have only recently been studied in more detail (Campanha \& Rocha-Campos, 1979; Anelli et al., 2002, 2006, 2009, 2012). Among the microfossils described by Campanha \& RochaCampos (1979) are foraminifers, conodonts, bryozoans, ostracods, microgastropods and microbivalves. Among the macroinvertebrates, the bivalve fauna is one of the most diverse of South American upper Paleozoic rocks (Anelli et al., 2009). Gastropods, cephalopods, brachiopods, bryozoans, and trilobites are also present, but in small number (Anelli, 1999; Anelli et al., 2009). Although Campanha \& Rocha-Campos (1979) and Anelli et al. (2009) mention the occurrence of brachiopods, there is no description or illustration of them. Therefore, we aim to describe the first occurrence of a Lingulidae in these beds.

The lingulide specimen was found at the Esperança facies, which is interpreted as deep marine (deposited in transgressive conditions), based on the taphonomic signatures of the invertebrates found (Anelli, 1999). Although the specimen was found in life position, only the ventral valve is preserved.

The fossils were collected from dolostone quarries of the Piauí Formation near the José de Freitas village, State of Piauí (Figure 1). Among 1,200 fossils collected, only one lingulide specimen was found, in beds of the Esperança Member. It is housed in the scientific collection of the Instituto de Geociências, Universidade de São Paulo (USP), under the code GP/1T 2304.

\section{Subphylum LINGULIFORMEA Williams, Carlson, Brunton, Holmer \& Popov, 1996 \\ Class LINGULATA Gorjanski \& Popov, 1985 Order LINGULIDA Waagen, 1885 Superfamily LINGULOIDEA Menke, 1828 Family LINGULIDAE Menke, 1828 \\ ?Lingularia Biernat \& Emig, 1993 (Figure 2)}

Type-species. Lingularia similis Biernat \& Emig, 1993.

Material. One ventral valve (GP/1T 2304).

Locality. Esperança Member, Piauí Formation, Parnaíba Basin.

Description. Ventral valve preserved as internal mold. Linguliform outline, parallel lateral sides, elongated, slightly convex. Anterior margin rounded. Maximum width at about mid-length. No external ornamentation is visible. No propareas distinguished. $1.8 \mathrm{~cm}$ long and $1.0 \mathrm{~cm}$ wide with a $\mathrm{W} / \mathrm{L}$ ratio of 0.55 . Visceral field of about $60 \%$ of the valve length. One pair of subtle pedicular nerve impressions observed, extending until the middle of the visceral field; apparently, 


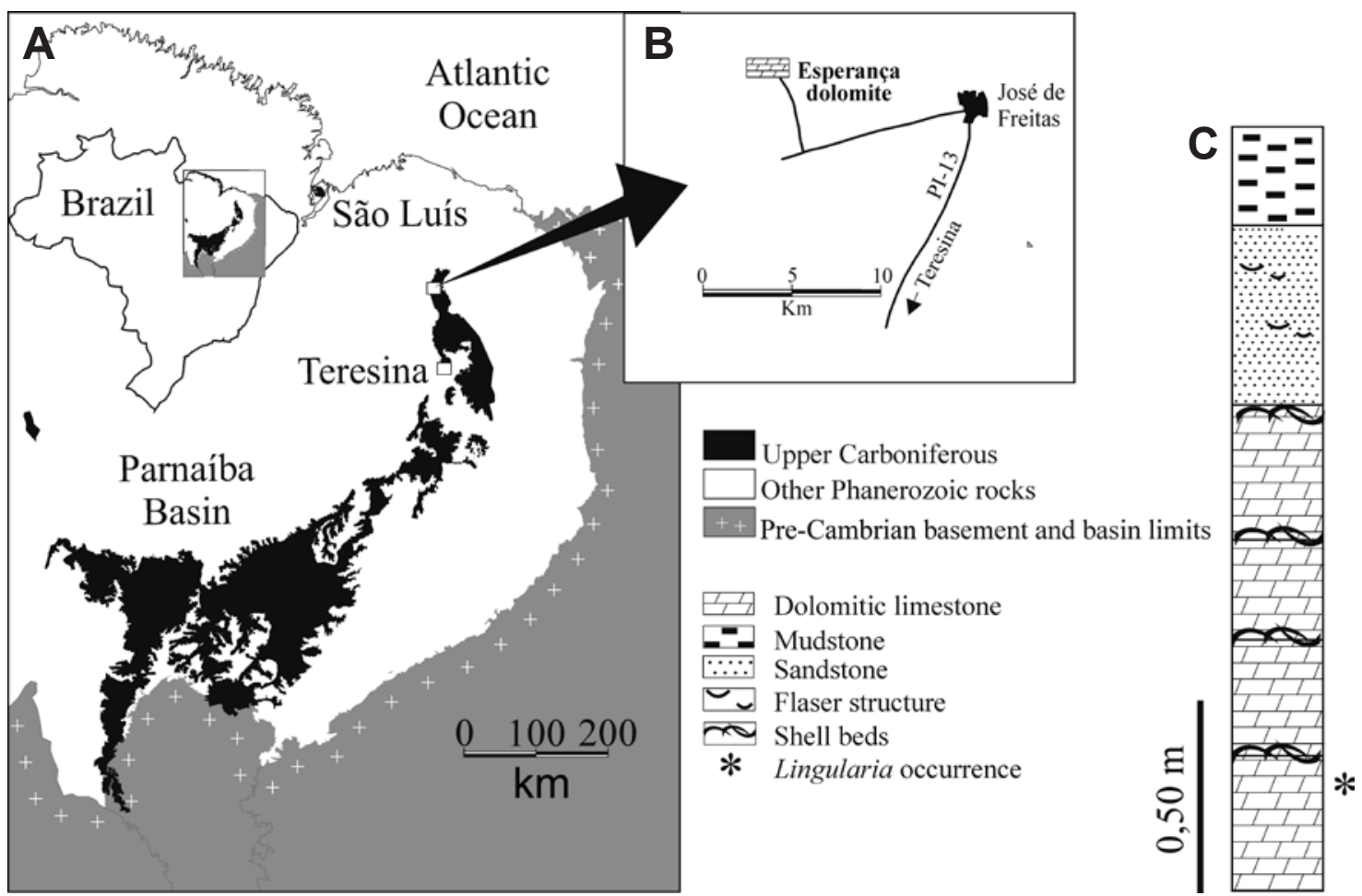

Figure 1. A, structural map showing the Piauí Formation (dark grey) in the Parnaíba Basin, northeastern Brazil; B, detail of the Esperança outcrop location; C, Esperança dolomite outcrop and the stratigraphical position of the Lingularia? sp. occurrence. Modified from Anelli et al. (2009).
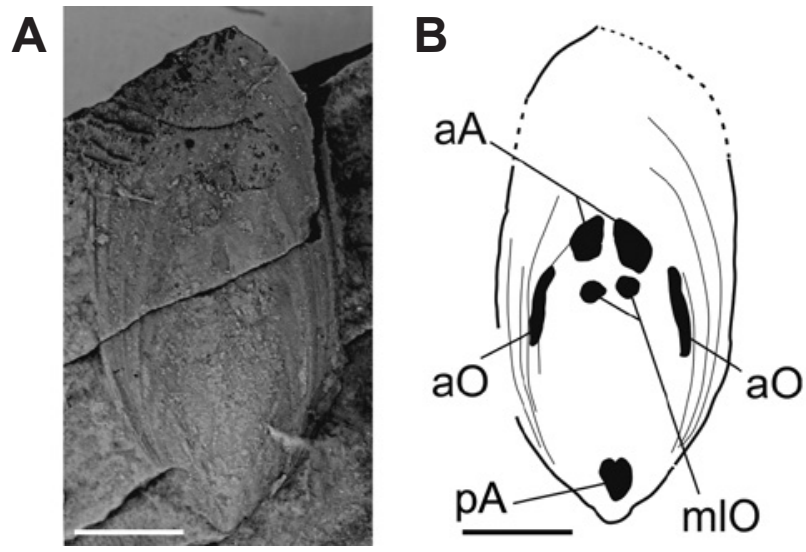

Figure 2. Specimen described in this paper and its muscle scars. A, ventral valve, internal mold. B, muscle scars based on the specimen, mirrored. Abbreviations: aA, anterior adductor; aO, anterior oblique; $\mathbf{m I O}$, median lateral oblique; $\mathbf{p A}$, posterior adductor. Scale bars $=50 \mathrm{~mm}$.

they do not converge near the posterior abductor (pA). A pair of V-shaped ridges opened in low angle extend posterolaterally until the first third of the visceral area. Anterior adductor $(\mathrm{aA})$ are clearly visible and placed above the midlength of the shell (Figure 2B). Median lateral oblique (mlO) muscle scars rounded, at the center of the valve, above aA. Anterior oblique $(\mathrm{aO})$ assymetric, long and teardrop shaped. Anterior internal oblique poorly visible. Posterior internal oblique not observed. Posterior adductor (pA) scar heart-like in outline (Figure 2B).

Comparisons. The specimen is assigned to Lingularia? on the basis of the following attributes: linguliform shape of the shell; W/L ratio of 0.55; pA heart-like; aO long and teardropshaped.. (Figure 2B). In spite of this, it cannot be assigned to Lingularia with certainty since only one ventral valve was recovered. Therefore, the authors choose to maintain the open nomenclature Lingularia? sp. Biernat \& Emig, 1993 (Bengtson, 1988). More data (i.e. more better-preserved valves) is necessary to secure a diagnosis avoiding withinpopulation variations and other biases (Biernat \& Emig, 1993). Apsilingula Williams, 1977 is described as having valves thickened posteriorly and deep muscular impressions. Although our specimen shows thickened muscular impressions (aA), the posterior part of the valve is not thickened. In Apsilingula, the ventral visceral area extends only to midvalve. Argentiella Archbold, Cisterna \& Sterren, 2005 differs from our specimen in having small distinct propareas and a broad median-ridge in ventral valve that is absent in our specimen. ?Barroisella Cooper, 1942 present small but prominent propareas, also absent in this specimen. ?Barroisella possess ventral visceral field extending only to mid-valve and the pedicle nerve possibly passing lateral to the umbonal muscle scar (pA). Credolingula Smirnova \& Ushtinskaya, 2001 differs from the valve described here in several aspects, such as the presence of plications, absent in our specimen; size of the visceral field area similar of about two-thirds of the valve length in Credolingula and in our specimen. Although Credolingula has a similar shaped $\mathrm{pA}$, it is joined with external and internal oblique muscle scars. In addition, at each valve Credolingula has two weak plications, which are absent in our specimen. Dignomia Emig \& Herrera, 2006 differs from our specimen mainly in having a median groove (septum internally) that extends 
from the umbonal region to the anterior half of the ventral valve which is absent in our specimen. The extant Glottidia Dall, 1870 differs from our specimen especially on the presence of internal septa. ?Langella Mendes, 1961, has a more rounded outline, and the main differences between ?Langella, ?Barroisella are revealed when comparing the dorsal valve, which is missing in this case; nonetheless both these genera have short descriptions and there is doubt about their family position (Holmer \& Popov, 2000). Lingula Brugière, 1797 differs from our specimen by its rounded pA scar and impressions of the pedicle nerves circulating this scar. In addition, its visceral area extends to midvalve, which is smaller than in our specimen. Semilingula Yegorov \& Popov, 1990 is described as similar to Lingularia, but with vestigial dorsal vascula media; nonetheless, we do not have the dorsal valve to compare. Sinolingularia Peng \& Shi, 2008 differs only in their rounded umbo, Sinolingularia being reported in millimeters and our specimen being centimetric. Sinoglottidia Peng \& Shi, 2008 differs from our specimen in having rounded umbo, ventral valve with $\mathrm{pA}$ scar rounded and internal septa in ventral valve.

\section{ACKNOWLEDGEMENTS}

C.Z. thanks to FAPESP (12/03517-1) for funding during this research. The authors thanks to C.C. Emig for comments and great improvements on the draft version, and for L. Holmer and M. Mergl for the great contributions as reviewers of this note. We also appreciate the language check made by $\mathrm{PhD}$ candidate $\mathrm{E}$. Schatz, from Memorial University of Newfoundland, Canada.

\section{REFERENCES}

Anelli, L.E. 1999. Invertebrados neocarboniferos das formações Piauí (Bacia do Parnaíba) e Itaituba (Bacia do Amazonas): taxonomia; análise cladistica das subfamílias Oriocrassatellinae (Crassatellacea, Bivalvia) e Neospiriferinae (Spiriferoidea, Brachiopoda). Programa de Pós-Graduação em Geologia Sedimentar, Universidade de São Paulo, Ph.D. thesis, 184 p.

Anelli, L.E.; Rocha-Campos, A.C. \& Simões, M.G. 2002. Protobranch bivalves of the Piauí Formation (Middle Pennsylvanian), Parnaíba Basin, Brazil. Revista Española de Paleontología, 17:165-176.

Anelli, L.E.; Rocha-Campos, A.C. \& Simões, M.G. 2006. Pennsylvanian Pteriomorphian (bivalvia) from the Piauí Formation, Parnaíba Basin, Brazil. Journal of Paleontology, 80:1125-1141. doi:10.1666/0022-3360(2006)80[1125:PPBFTP]2.0.CO;2

Anelli, L.E.; Rocha-Campos, C.; Simões, M.G. \& Peck, R.L. 2009. Pennsylvanian Heteroconchia (Mollusca, Bivalvia) from the Piauí Formation, Parnaíba Basin, Brazil. Revista Brasileira de Paleontologia, 12:93-112. doi:10.4072/rbp.2009.2.01

Anelli, L.E.; Simões, M.G.; González, C.R. \& Souza, P.A. 2012. A new Pennsylvanian Oriocrassatellinae from Brazil and the distribution of the genus Oriocrassatella in space and time. Geodiversitas, 34:489-504. doi:10.5252/g2012n3a2

Archbold, N.W.; Cisterna, G.A. \& Sterren, A.F. 2005. Lingulida (Brachiopoda) from the Early Permian of Argentina. Proceedings of the Royal Society of Victoria, 112:307-317.
Bengtson, P. 1988. Open nomenclature. Palaeontology, 31:223-227. Biernat, G. \& Emig, C.C. 1993. Anatomical distinctions of the Mesozoic lingulide brachiopods. Acta Palaeontologica Polonica, 38:1-20.

Bigarella, J.J.; Mabesoone, J.M.; Lins, C.J.C. \& Mota, F.O. 1965. Paleogeographical features of the Serra Grande and Pimenteira formations (Parnaíba Basin, Brazil). Palaeogeography, Palaeoclimatology, Palaeoecology, 1:259296. doi:10.1016/0031-0182(65)90019-2

Bruguière, R.E.M. 1797. Tableau Encyclopédique et méthodique des Trois Règnes de la nature: Vers, Coquilles, Mollusques et Polypiers, 190-286.

Campanha, V.A. \& Rocha-Campos, A.C. 1979. Alguns microfósseis da Formação Piauí (Neocarbonífero), Bacia do Parnaíba. Boletim do Instituto de Geociências, 10:57-67.

Clarke, J.M. 1913. Fósseis devonianos da Bacia do Paraná. Rio de Janeiro, Serviço Geológico e Mineralógico do Brasil, 353 p. (Monografias 1).

Comniskey, J.C. 2011. Paleontologia dos Discinidae (Brachiopoda: Linguliformea) da sucessão devoniana da Bacia do Paraná, Estado do Paraná, Brasil: Revisão sistemática, distribuição geográfica e estratigráfica. Programa de Pós-graduação em Geografia, Universidade Estadual de Ponta Grossa, M.Sc. thesis, 180 p.

Cooper, S.A. 1942. New genera of North American brachiopods. Washington Academy of Sciences Journal, 32:228-235.

Dall, W.H. 1870. A revision of the Terebratulidae and Lingulidae. American Journal of Conchology, 6:177-204.

Emig, C.C. \& Herrera, Z. 2006. Dignomia munsterii (Brachiopoda, Lingulata) from the Ordovician of Bolivia, with redescription of the genus. Geodiversitas, 28:227-237.

Grahn, Y. \& Caputo, M.V. 1992. Early Silurian glaciations in Brazil. Palaeogeography, Palaeoclimatology, Palaeoecology, 99:9-15. doi:10.1016/0031-0182(92)90003-N

Gray, J.; Colbath, G.K.; Faria, A.; Boucot, A.J. \& Rohr, D.M. 1985. Silurian-age fossils from the Paleozoic Paraná Basin, southern Brazil. Geology, 13:521-525. doi:10.1130/00917613(1985)13<521:SFFTPP $>2.0$. CO;2

Holmer, L.E. \& Bengtson, P. 2009. The first occurrence of a lingulid brachiopod from the Cretaceous of Sergipe, Brazil, with a restudy of "Lingula" bagualensis Wilckens, 1905 from southern Patagonia. Paläontologische Zeitschrift, 83:255-266. doi:10.1007/s12542-009-0024-6

Holmer, L.E. \& Popov, L.E. 2000. Lingulidae. In: R.L. Kaesler (ed.) Treatise on invertebrate paleontology, part H, Brachiopoda revised, Geological Society of America and University of Kansas Press, p. 35-39.

Melo, J.H.G. \& Boucot, A.J. 1990. Harringtonina is Anabaia (Brachiopoda, Silurian, Malvinokaffric Realm). Journal of Paleontology, 64:363-366. doi:10.1017/S0022336000018564

Mendes, J.C. 1961. Langella, novo gênero de lingulídeo da série Tubarão. Boletim da Universidade do Paraná, 5:1-8.

Menke, C.T. 1828. Synopsis methodica molluscorum generum omnium et specierum earum quae in Museo Menkeano adservantur, G.Uslar Pyrmonti. Available at http://www.biodiversitylibrary. org/item/47244\#page/5/mode/1upa; accessed on 06/06/2016.

Peng, Y. \& Shi, G.R. 2008. New early Triassic Lingulidae (Brachiopoda) genera and species from South China. Alcheringa, 32:149-170. doi:10.1080/03115510801944988

Ponciano, L.C.M.O.; Castro, A.R.S.F.; Fonseca, V.M.M. \& Machado, D.M.C. 2012. Tafocenose da Formação Pimenteira, Devoniano da Bacia do Paraníba, Piauí: mapeamento, inventário e relevância patrimonial. Anuário do Instituto de Geociências, 35:5-27. doi:10.11137/2012_1_05_27 
Queiroz, J.P.; Gama Jr., J.M. \& Pires, E.F. 2013. Ocorrência de braquiópodes fósseis no entorno do Rio Balsas, Município de Santa Teresa, Estado do Tocantins, em estratos da Formação Pimenteira, Devoniano da Bacia do Parnaíba. Brazilian Geographical Journal: geosciences and humanities research medium, 1:191-212.

Rathbun, R. 1878. The Devonian Brachiopoda of the Province of Pará, Brazil. Proceedings of the Boston Society of Natural History, 20:15-39.

Smirnova, T.N. \& Ushatinskaya, G.T. 2001. New lingulids (Brachiopoda) from the Lower Cretaceous of European Russia, with notes on the microstructure of their shells. Palaeontological Journal, 35:387-395.

Williams, A.J. 1977. Insight into lingulid evolution from the Late Devonian. Alcheringa, 1:401-406. doi:10.1080/03115517708527775

Yegorov, A.N. \& Popov, L.Y. 1990. A new Lower Permian lingulid from the Siberian Platform. Paleontologicheskii Zhurnal, 4:111-115. [in Russian].
Zabini, C.; Bosetti, E.P. \& Holz, M. 2010.Taphonomy and taphofacies analysis of lingulid brachiopods from Devonian sequences of the Paraná Basin, Brazil. Palaeogeography, Palaeoclimatology, Palaeoecology, 292:44-56. doi:10.1016/j.palaeo.2010.03.025

Zabini, C.; Bosetti, E.P.; Horodyski, R.S. \& Matsumura, W.M.K 2007. Lingulídeos: revisão dos conceitos morfo-anatômicos, fisiológicos, reprodutivos, paleo-ecológicos e a importância do grupo no Devoniano da região dos Campos Gerais do Paraná, Brasil.Terr@Plural,1:115-122.

Zabini, C.; Comniskey, J.C. \& Bosetti, E.P. 2013. John Mason Clarke e os lingulídeos e discinídeos dos estratos devonianos da Bacia do Paraná, estado do Paraná, Brasil: estado da arte.Terr@Plural, 7:43-58. doi:10.5212/TerraPlural.v.7iEspecial.0004

Zabini, C.; Holz, M.; Bosetti, E.P.; Matsumura, W.M.K. \& Horodyski, R.S. 2012. Sequence stratigraphy and taphonomic signatures of marine invertebrates: a Devonian (Pragian/Eifelian) example of the Paraná Basin. Journal of South American Earth Sciences, 33:8-20. doi:10.1016/j.jsames.2011.08.001

Received in March, 2016; accepted in October, 2016. 